\title{
Domestic Welfare Effects of Foreign Strategic Trade Policies
}

\author{
Philippe Kohler \\ Institut d'Etudes Politiques de Paris \\ Michael O. Moore \\ The George Washington University
}

\begin{abstract}
Within a duopoly strategic trade policy model, we analyze the effect of foreign strategic trade policies on domestic welfare when the domestic government pursues a laissez-faire import policy. With Cournot competition and domestic production and consumption, an increase in the foreign strategic export subsidy increases domestic welfare when the domestic price exceeds the foreign firm marginal cost. With Bertrand competition, an increase in the foreign strategic export tax has ambiguous effects on domestic welfare and depends on the degree of product differentiation and domestic cross-price elasticity of demand between domestic and foreign goods.
\end{abstract}

- JEL Classifications: F13

- Key words: Dumping, Laissez-faire policy, Strategic trade policy.

\section{Introduction}

Even if optimal trade policies under oligopoly have been widely studied ${ }^{1}$ some

\footnotetext{
*Corresponding address: Doctor Philippe Kohler, Institut d'Etudes Politigues de Paris 2, Sguare de Luynes 75007- Paris, France Tel: 33-1-4559-7256, Fax: 31-1-4549-7257, E-mail: philippe.kohler@ sciences-po.fr

Professor Michael O. Moore, The George Washington University, Department of Economics and Elliott School of International Affairs, Washihation DC 20052, USA. Tel: 202-994-6157, Fax: 202-994-6147, E-mail: mom@gwu.edu (C2003-Center for International Economics, Sejong Institution, All Rights Reserved.

${ }^{1}$ See Brander (1995) for an extensive survey.
} 
analytical points have been missed and merit attention. In this paper, we focus on one of those points: the welfare implication of a passive domestic response to active foreign trade policies under oligopoly. We find that in a broad array of situations, domestic welfare is not harmed by adherence to a simple laissez-faire trade policy, even in the face of foreign "optimal" foreign intervention. These results therefore provide further support for countries deciding not to attempt to pursue interventionist "strategic trade policies" and adhering instead to relatively easy-to-implement free trade approaches.

The literature on strategic trade policies has generally taken two directions: on the one hand, emphasis has been put on the design of domestic policies on foreign markets given agents' characteristics. ${ }^{2}$ On the other hand, normative reasons for active responses to foreign policies have been investigated.

Dixit (1988) provides a systematic treatment of this latter approach. He analyzes the domestic optimal trade and industrial policies (including domestic subsidies and tariffs on foreign goods) in response to foreign government subsidies and foreign firm dumping. ${ }^{3}$ In the case of foreign dumping, the main result is that no normative reason can be found to modify the home government optimal strategic policy in order to respond to a modification of the foreign firm strategic choice (i.e., the dumping margin). However, in the case of foreign subsidies, Dixit shows that a countervailing tariff ${ }^{4}$ is justified from a home welfare point of view in order to offset an increase in the foreign government strategic choice (i.e., an export subsidy). Collie (1991b) builds on Dixit by focusing both on foreign incentives for export subsidies in the presence of home retaliation through tariffs and production subsidies and on the home and foreign welfare effect of such retaliation. He finds that a foreign export subsidy always increases domestic welfare if the domestic country pursues an optimal trade policy, but, in some cases, such a response does not negate the profit-shifting argument for export subsidies. If the home government can only use the tariff to countervail the foreign strategic trade policy and if this tariff is set optimally, then it gains from the foreign export subsidy. However, if the foreign country anticipates the

\footnotetext{
${ }^{2}$ One set of authors has focused on the supply side of the model (i.e., the nature of the duopolistic competition). They include Eaton and Grossman (1985), Laussel (1992), and Maggi (1996). (See Caillaud et al. (1995), and Brainard and Martimort (1997) for the treatment and implications of agency problems arising from incomplete information problems.) Others, including Bandopadhya (1997) and Neary (1994) have focused more on the structure of demand.
}

${ }^{3}$ Cheng (1988) develops similar work in this field.

${ }^{4}$ The duty should only partially countervail the foreign policy as shown by Collie (1991a). 
home optimal response, the foreign incentives for profit shifting subsidy shift into an export tax motive.

Collie (1991b) thus points out that "rational" strategic foreign export subsidies generally only exist when optimal home optimal responses do not. In the case of anticipated home retaliation through tariffs, the optimal strategic trade policy is an export tax. Our paper follows Collie (1991b) but adopts a complementary approach by assuming that the domestic government does not intervene in response to the foreign strategic trade policy. We analyze this issue first with a strategic foreign export subsidy and second in the case of a foreign export tax. In each case, we ask how home welfare is affected by these policies when the home country does not intervene.

We assume that domestic welfare consists of the sum of consumer surplus and producer profit so that tariff/subsidy budget effects are ignored. We show that with Cournot competition (i.e., when strategic variables are substitutes), while the domestic firm suffers from the foreign subsidy, the home country's consumers always gain enough from a small increase in the strategic foreign subsidy to increase net domestic welfare, as long as the foreign firm's price exceeds its marginal production cost, i.e., it is not dumping. In the Bertrand case with differentiated products (strategic complements), the foreign export tax helps the domestic firm but harms the domestic consumer. The net effect on domestic welfare with a domestic laissez-faire policy depends on a number of parameters, including most importantly the cross-price elasticity of domestic demand between domestic and foreign output. But once again, we find that domestic welfare can rise with foreign optimal intervention. ${ }^{5}$

\section{Welfare Effects of Strategic Trade Policies in the Case of a Laissez-faire policy}

\section{A. Cournot Competition-Strategic Substitutes}

Consider a domestic and a foreign firm producing a homogenous good and competing in a Cournot fashion. For the sake of simplicity, the domestic firm's output is produced only for its home market while the foreign firm sells all of its output $y$ in

\footnotetext{
${ }^{5}$ Anderson et al. (1995) analyze antidumping tariffs in a Bertrand and Cournot model and find similarly that no intervention would be optimal for the domestic government. Blonigen et al.(1999) also find in computable general equilibrium model that duties placed on "unfairly" traded imports have significant welfare costs.

${ }^{6}$ This setup is therefore slightly different from the standard Brander-Spencer model in which the countries' two duopolies compete in a third market.
} 
the domestic market. ${ }^{6}$ Total domestic supply of the good is given by $Q=y+x$ and $P(Q)$ denotes the domestic inverse demand for the good. Within the Cournot duopolistic interaction, quantities act as strategic substitutes: a marginal increase of the foreign firm supply reduces the domestic firm marginal profit. The domestic firm has to reduce its own supply in order to restore its profit maximization condition, i.e., a zero marginal profit.

In this case, we analyze the welfare impact of a foreign strategic subsidy when the domestic government pursues a unilateral laissez-faire trade policy: no tariff revenue is collected nor is a domestic subsidy granted. Domestic welfare $W$ is thus given by the sum of consumer surplus $C S$ and domestic profit $\pi$.

$$
W=C S+\pi
$$

where $C S$ is given by:

$$
\int_{0}^{Q} P(v) \cdot d v-P(Q) \cdot Q
$$

The domestic (foreign) production technologies are based on a constant marginal cost $c\left(c^{*}\right)$ and a fixed cost $F\left(F^{*}\right) .{ }^{7}$ We assume that the foreign government policy consists of choosing the per-unit strategic export subsidy level $s^{*}$ to maximize foreign welfare. Domestic and foreign profits are, respectively:

$$
\begin{gathered}
\pi(x, y)=(P(Q)-c) \cdot x-F \\
\pi^{*}(x, y)=\left(P(Q)-c^{*}+s^{*}\right) \cdot y-F^{*}
\end{gathered}
$$

As in the standard case, the strategic rent shifting effect allowed by the foreign subsidy can be shown by computing and differentiating the first order conditions for domestic and foreign profit maximization in the duopoly:

$$
\begin{gathered}
\pi_{x}=\frac{d \pi(x, y)}{d x}=P-c+x \cdot P^{\prime}=0 \\
\pi_{y^{*}}=\frac{d \pi^{*}(x, y)}{d y}=P-c^{*}+s^{*}+y \cdot P^{\prime}=0
\end{gathered}
$$

where $P^{\prime}=d P / d Q<0$. Following Brander and Spencer (1985), at the CournotNash equilibrium, the foreign optimal strategic subsidy, denoted by $\tilde{s}^{*}$, is given by:

$$
\tilde{s}^{*}=\pi_{x^{*}} \cdot \frac{d x / d s^{*}}{d y / d s^{*}}=-\pi_{x^{*}} \frac{\pi_{x y}}{\pi_{x x}}=y \cdot P^{\prime} \cdot \frac{d x / d s^{*}}{d y / d s^{*}}
$$

${ }^{7}$ Foreign variables are denoted with an asterisk. Subscripts refer to derivatives. 
where:

$$
\pi_{x x} \equiv \partial^{2} \pi / \partial x^{2}, \pi_{x y} \equiv \partial \pi_{x} / \partial y, \pi_{y x}^{*} \equiv \partial \pi_{y}^{*} / \partial x, \pi_{y y}^{*} \equiv \partial^{2} \pi / \partial y^{2}
$$

Assuming stability of the Nash equilibrium and that decision variables are strategic substitutes, we have the standard result that the foreign optimal export subsidy is positive. As is well known in these models, domestic output falls as a consequence of the subsidy, $d x / d s^{*}<0$, while foreign output rises: $d x / d s^{*}>0$. Moreover, foreign output rises more than domestic output falls so that total supply in the domestic market rises, i.e., $d Q / d s^{*}>0$.

From a domestic welfare viewpoint, Dixit (1988) and Collie (1991b) have shown that foreign subsidies are desirable when the domestic government can respond optimally through the extraction of the shifted rent with a tariff on imports. However, Brander and Spencer (1984) had also shown that, with no domestic production, the efficient response to foreign firm market power can be an import subsidy. ${ }^{8}$ We ask a different question: are foreign subsidies harmful when the domestic government's policy is free trade? In other words, if a government decides to follow the simplest of all trade rules (non-intervention), will domestic welfare be hurt by the foreign attempts to increase firm rents?

Taking into account the situation where the foreign government sets the optimal value of the subsidy, we compute the domestic welfare change in a hypothetic situation where the optimal subsidy level is increased at the margin. If the domestic welfare varies positively (negatively) with the foreign subsidy, then the foreign use of subsidy is domestically welfare improving (worsening) if the domestic government retains a laissez-faire policy. ${ }^{9}$

Consider first domestic welfare, which can be re-written as:

$$
W=\int_{0}^{Q} P(v) \cdot d v-P(Q) \cdot Q+(P-c) \cdot x-F
$$

\footnotetext{
${ }^{8}$ This points out the second best nature of the problem: the subsidy reduces the imperfect competition distortion.

${ }^{9} \mathrm{We}$ assume that the domestic welfare varies monotonically with the optimal level of the foreign export subsidy.

${ }^{10}$ One can argue that $s^{*}$ is determined endogenously and depends on $\pi$ or, more accurately, on $c$. If we assume that $c$ is constant then $s^{*}$ depends exclusively on parameters exogenous to domestic firm characteristics (see Collie (1991b) for an analogous derivation method).
} 
The domestic welfare effect of a change in the foreign subsidy $s^{*}$ is given by the sum of consumers and firm profit effects: ${ }^{10}$

$$
\frac{d W}{d S^{*}}=\frac{d C S}{d s^{*}}+\frac{d \pi}{d s^{*}}
$$

The domestic consumer surplus effect of the subsidy increase is given by:

$$
\frac{d C S}{d s^{*}}=P \cdot \frac{d Q}{d s^{*}}-\left[P \cdot \frac{d Q}{d s^{*}}+Q \cdot P^{\prime} \cdot \frac{d Q}{d s}\right]=-Q \cdot P^{\prime} \cdot \frac{d Q}{d s^{*}}
$$

Expression (11) shows that the consumer surplus rises with an increase in the foreign subsidy since overall supply increases $\left(d Q / d s^{*}>0\right)$ and the demand curve is downward sloping $\left(P^{\prime}<0\right)$.

On the other hand, the effect of the subsidy change on domestic profits is given by:

$$
\frac{d \pi}{d s^{*}}=(P-c) \cdot \frac{d x}{d s^{*}}+x \cdot P^{\prime} \cdot \frac{d Q}{d s^{*}}<0
$$

Since we know that $d Q / d s^{*}>0$ and that overall supply rises, domestic profit falls with the increase in the foreign subsidy. Given that $Q=x+y$, the overall domestic welfare effect of a subsidy increase is therefore given by:

$$
\frac{d W}{d s^{*}}=-y \cdot P^{\prime} \cdot \frac{d y}{d s^{*}}+\left(P-c-y \cdot P^{\prime}\right) \cdot \frac{d x}{d s^{*}}
$$

Thus, an increase of the foreign subsidy will increase domestic welfare if:

$$
\frac{d W}{d s^{*}}>0 \Leftrightarrow-y \cdot P^{\prime} \cdot \frac{d y}{d s^{*}}+\left(P-c-y \cdot P^{\prime}\right) \cdot \frac{d x}{d s^{*}}>0
$$

Dividing the right hand side of this expression by $P$ yields:

$$
\left[\frac{-y \cdot P}{P} \cdot \frac{d y}{d s^{*}}\right]+\left[\frac{P-c}{P}-\frac{y \cdot P^{\prime}}{P}\right] \cdot \frac{d x}{d s^{*}}>0
$$

Let $\varepsilon$ denote the price elasticity of the inverse demand on the home market and $z\left(z^{*}\right)$, the market share of the domestic (foreign) firm:

$$
\varepsilon \equiv \frac{P}{-Q \cdot P^{\prime}} \quad z \equiv \frac{x}{Q} \quad z^{*} \equiv \frac{y}{Q}
$$

By using (16), we can rewrite condition (15) as: 


$$
\frac{z^{*}}{\varepsilon} \cdot\left[\frac{d x}{d s^{*}}+\frac{d y}{d{ }^{*}}\right]+\left[\frac{P-c}{P}\right] \cdot \frac{d x}{d s^{*}}>0
$$

In (17), the first term (positive) exhibits a consumption effect due to the net supply variation of the good in the domestic economy and the second term (negative) denotes a domestic firm profit effect due to the loss of the domestic firm as it reduces its output.

Condition (17) shows that the smaller is the foreign share in the domestic market, the smaller is the positive consumption effect of the increased subsidy and the more likely that the domestic firm profit negative effect will dominate. In a Cournot duopoly, a low foreign firm market share in the domestic market implies a high foreign marginal cost relative to the domestic firm marginal cost. As shown by Neary (1994), such a situation implies an intrinsically low optimal foreign strategic export subsidy: the profit shifting effect of the export subsidy is low. Paradoxically, domestic consumers are thus negatively affected by the inefficiency of the foreign firm. In addition, the more elastic domestic demand, the less important will be the consumption positive effect. In the limit, a perfectly elastic domestic demand curve will mean that the only effect will be the domestic firm profit negative effect. These conditions for a welfare improvement will hold for any foreign subsidy increase that causes domestic output to fall but overall supply in the domestic market to increase.

Now what is the domestic welfare effect of a marginal increase in a subsidy chosen optimally (i.e.; $s^{*}=\tilde{s}^{*}$ ) by the foreign government? We can use the domestic firm's first-order conditions (6) as well as the definition of $\varepsilon$ to re-write the domestic price-cost markup as:

$$
\frac{P-c}{P}=-\frac{x \cdot P^{\prime}}{P}=\frac{x}{Q} \cdot \frac{-Q \cdot P^{\prime}}{P}=\frac{z}{\varepsilon}
$$

Using (18) along with the formula for the optimal foreign subsidy (7) allows us to provide another version of the condition (17) for a domestic welfare improvement:

$$
\left[\frac{z}{\varepsilon}+\frac{z^{*}}{\varepsilon}\right] \cdot\left[\frac{d x}{d \tilde{s}^{*}} / \frac{d y}{d \tilde{s}^{*}}\right] \cdot \frac{P-c}{P}>-\frac{z^{*}}{\varepsilon}
$$

Condition (19) is equivalent to:

$$
\frac{\tilde{s}^{*}}{\varepsilon \cdot y \cdot P^{\prime}}>-\frac{z^{*}}{\varepsilon}
$$


Consider the right hand side of (20). Given that $\varepsilon>0$ and $y \cdot P^{\prime}<0$, the home welfare effect is positive if:

$$
\tilde{s}^{*}<-y \cdot P^{\prime} \cdot z^{*}
$$

Using the fact that $-y \cdot P^{\prime}=P / \varepsilon$, condition (21) can be rewritten as:

$$
\frac{\tilde{s}^{*}}{P}<\frac{z^{*}}{\varepsilon}=\frac{-y \cdot P^{\prime}}{P}
$$

We know from (6) that $-y \cdot P^{\prime}=\left(P-c^{*}+\tilde{s}^{*}\right)$. Hence, condition (22) can be rewritten as

$$
\frac{\tilde{s}^{*}}{P}<\frac{P-c^{*}+\tilde{s}^{*}}{P}
$$

Thus, an increase in the optimal foreign subsidy will increase domestic welfare only if:

$$
\left.\frac{d W}{d s^{*}}\right|_{s^{*}=\tilde{s}^{*}}>0 \Leftrightarrow P-c^{*}>0
$$

Condition (24) allows us to give the following proposition:

Proposition 1. With strategic substitutes, an increase in the optimal foreign strategic subsidy increases the welfare of a laissez-faire domestic economy, as long as the foreign firm's price in the domestic market exceeds its own marginal production cost.

If the foreign firm is selling below its production cost then a marginal increase in the optimal foreign export subsidy will decrease domestic welfare. One might be tempted to interpret this result as a justification for antidumping and countervailing duty laws - if the foreign firm is uncompetitive and must use a subsidy to overcome its high costs, then the domestic consumer benefits of the lower prices is outweighed by the "inappropriate" shifting of profits from the costefficient domestic firm. However, would it ever make economic sense for the foreign government to subsidize a loss-making firm? In particular, since foreign welfare is given by:

$$
W^{*}=\left(P(Q)-c^{*}+s^{*}\right) \cdot y-F^{*}-s^{*} \cdot y=\left(P(Q)-c^{*}\right) \cdot y-F^{*}
$$


any positive foreign production yields negative welfare. Thus, no foreign subsidy and no foreign production should occur for governments with this objective function.

If instead the foreign firm does cover its costs through exports to the domestic market, then an increase in the foreign government's optimal subsidy will increase domestic consumer welfare enough to offset any profit loss. When might the foreign subsidy increase beyond the original optimal level?

One possibility is that the foreign government might inadvertently increase the subsidy beyond the optimal level, say, because of poor information about the foreign firm market structure. This increased subsidy will increase overall foreign firm output beyond the optimal level; i.e., too much output, too low a price, and too high of a subsidy cost. Nonetheless, as long as the foreign firm is not dumping, then the falling prices in the domestic market is beneficial to overall domestic welfare. This result is not that different from standard perfectly competitive frameworks-a subsidy generally will help consumers more than it hurts domestic firms.

\section{B. Bertrand Competition-Strategic Complements}

Consider now the Bertrand duopoly case. Denote the domestic demand for the domestic firm output (the foreign firm output) by $x\left(P, P^{*}\right)\left(y\left(P, P^{*}\right)\right)$, where $P\left(P^{*}\right)$ is the price set by the domestic firm (foreign firm). We assume that the domestic and foreign goods are imperfect substitutes in domestic consumption, $x_{P^{*}}>0$ and $y_{P}>0$ so that prices act as strategic complements: a marginal increase of the foreign firm price increases the domestic firm marginal profit. The domestic firm has to increase its own price in order to restore its profit maximization condition, i.e.; a zero marginal profit.

In this case, the foreign trade policy consists of committing to impose an export $\operatorname{tax} t^{*}$ on the output sold by the foreign firm in the domestic market. Domestic firm and foreign firm profit functions are, respectively:

$$
\begin{gathered}
\pi\left(P, P^{*}\right)=(P-c) \cdot x\left(P, P^{*}\right)-F \\
\pi^{*}\left(P, P^{*}, t^{*}\right)=\left(P-c^{*}-t^{*}\right) \cdot y\left(P, P^{*}, t^{*}\right)-F^{*}
\end{gathered}
$$

Taking $t^{*}$ as given, firms set prices in a Bertrand context in order to maximize their profits. First order conditions are given by: 


$$
\begin{gathered}
\pi_{P}=\frac{\partial \pi}{\partial P}=x_{P} \cdot(P-c)+x=0 \\
\pi_{P^{*}}^{*}=\frac{\partial \pi^{*}}{\partial P^{*}}=y_{P^{*}} \cdot\left(P^{*}-c^{*}-t^{*}\right)+y=0
\end{gathered}
$$

Differentiation of first-order conditions and standard computation gives the effect of the foreign export tax on domestic and foreign strategic variables:

$$
\frac{d P}{d t^{*}}>0, \quad \frac{d P^{*}}{d t^{*}}>0
$$

The optimal foreign export tax value denoted by $\tilde{t}^{*}$ emerges from the foreign government welfare maximization problem:

$$
\max _{t^{*}} W^{*}\left(t^{*}\right)=\pi^{*}\left[P\left(t^{*}\right), P^{*}\left(t^{*}\right), t^{*}\right]+t^{*} \cdot y\left[P\left(t^{*}\right), P^{*}\left(t^{*}\right)\right]
$$

and equals:

$$
\tilde{t}^{*}=-\left(P^{*}-c^{*}\right) \cdot \frac{y_{P}}{y_{P^{*}}} \cdot\left[\frac{d P\left(t^{*}\right)}{d t^{*}} / \frac{d P^{*}\left(t^{*}\right)}{d t^{*}}\right]
$$

Expression (17) shows that if the foreign price exceeds foreign cost (i.e., $P^{*}-$ $c^{*}>0$ ), then the optimal policy of the foreign government concerned only with firm profit would be an export tax. If the opposite is true (i.e., $P^{*}-c^{*}<0$ ), then one might expect an optimal export subsidy and the foreign government in fact would not intervene: as in the previous section, it is clear from the definition of foreign welfare that foreign profit net of the tax will always be negative for $P^{*}-c^{*}<0$. The foreign firm will therefore shut down without the subsidy.

Consider now the welfare of the domestic country, defined in a way analogous to (1):

$$
W=\int_{P}^{\infty} x\left(v, P^{*}\right) \cdot d v+\int_{P^{*}}^{\infty} y(P, v) \cdot d v+\pi\left(P, P^{*}\right)
$$

For an arbitrary change in the foreign intervention, we have:

$$
\frac{d W}{d t^{*}}=-x \cdot \frac{d P}{d t^{*}}-y \cdot \frac{d P^{*}}{d t^{*}}+(P-c) \cdot x_{P} \cdot \frac{d P^{*}}{d t^{*}}
$$

In the right-hand side of (34), the first two terms show the consumption effect of the foreign intervention: an export tax increase, with a consequent rise in domestic and foreign prices, will hurt consumers. The third term is the domestic profit effect: a foreign price increase allows for the domestic firm to increase its 
sales and hence its profits. If the profit effect outweighs the consumption effect then the foreign export tax increase improves domestic welfare.

Assume that the foreign government chooses $t^{*}$ optimally. The domestic welfare effect of a marginal change in the neighborhood of the optimal value $\tilde{t}^{*}$ is obtained by combining $d P^{*} / d t^{*}$ from (32) the optimal intervention condition with (34):

$$
\left.\frac{d W}{d t^{*}}\right|_{t^{*}=\tilde{t}^{*}}=\frac{d P}{d t^{*}} \cdot\left[\left(-x-y+(P-c) \cdot x_{P^{*}}\right) \cdot\left(-\left(P^{*}-c^{*}\right) \cdot \frac{y_{P}}{y_{P^{*}}} \cdot P^{*} \cdot \frac{1}{\tilde{t}^{*}}\right)\right]
$$

In (35), assume that the foreign firm is selling above its marginal cost (i.e., $P^{*}$ $\left.-c^{*}>0\right)$. Since we have $y_{p}<0$ and $y_{P^{*}}>0$, the domestic welfare effect of the optimal foreign export tax increase will depend on whether $\left(-x-y+(P-c) \cdot x_{P^{*}}\right)$ is positive. This condition simply shows the induced marginal impact on domestic consumers as domestic and foreign prices rise as well as the marginal domestic firm profit effect due to the foreign price increase.

Using (35), we can rewrite the condition for a domestic welfare improvement as:

$$
\frac{P-c}{P}>\frac{P^{*}}{P} \cdot \frac{1}{\varepsilon_{x / y}} \cdot\left[\frac{\tilde{t}^{*}}{P^{*}-c^{*}} \cdot\left(-\frac{y_{P^{*}}}{y_{P}}\right)+\frac{y}{x}\right]
$$

with:

$$
\varepsilon_{x / y}=\frac{\partial x}{\partial P^{*}} \cdot \frac{P^{*}}{x}
$$

Condition (36) relates the domestic price-cost markup to two domestic demand parameters: the cross-price elasticity of domestic demand $\varepsilon_{x / y}$ and the degree of products differentiation.

First, if $\varepsilon_{x / y}$ is sufficiently high, then the increase in the foreign tax is welfareimproving. This means that the domestic firm could see sufficient strength in domestic sales and the subsequent higher domestic profits to offset the increased burden on domestic consumers. Thus, unlike the Cournot case, it is not enough to show that foreign firms are not dumping for the foreign scheme to be welfareenhancing: it depends on how much domestic consumers switch their consumption of domestic output relatively to foreign output as prices increase as a consequence of the foreign government intervention.

Second, in the case of linear demands, $-y_{P^{*}} / y_{P}$ can be considered the brands' measure of differentiation (BMD). In particular, suppose that differentiated demands are given by $x=a-b P+c P^{*}$ and $y=a+c P-b P^{*}$ then the BMD is 
given by $-y P^{*} / y P$ which equals $c / b$. Thus, a BMD is close to zero (one) for highly differentiated (almost homogeneous) brands. ${ }^{11}$

It is clear from (36) that as BMD approaches zero, the more likely it is that an increase in the foreign export intervention will improve domestic welfare-close substitutes makes the price collusion device induced by the export tax more difficult to implement. The reverse is true-as the degree of differentiation rises (i.e., BMD approaches 1), the less likely it is that the increased foreign intervention will increase domestic welfare.

The following proposition summarizes the interpretation of condition (36):

Proposition 2. With strategic complements and domestic laissez-faire, an increase in the optimal foreign intervention is more likely to increase domestic welfare: a) the larger is $\varepsilon_{x / y} b$ ) the less differentiated are the domestic and foreign products $c$ ) the larger is the domestic price-cost markup d) the smaller the value of foreign imports relative to the value of domestic production.

\section{Concluding Remarks}

Within a duopoly model of strategic trade policy, we have studied the welfare implications of a domestic government's passive response to a foreign strategic intervention. The domestic government laissez-faire policy consists of ignoring any possibility of increasing tariff revenues or subsidizing the domestic firm. Instead, the government considers only the sum of domestic consumer surplus and domestic profit.

With strategic substitutes under Cournot-Nash competition, a foreign export subsidy will increase domestic welfare as long as the foreign production cost is below the price it charges in the domestic market. This result surprisingly mitigates the welfare argument for a home strategic response to a more aggressive foreign firm behavior on a home Cournot duopolistic market.

With Bertrand-Nash competition with differentiated products, the impact of a foreign intervention depends mainly on the degree of substitutability between domestic and foreign goods. If a change in prices causes domestic consumers to switch their purchases sufficiently towards the domestic firm's output from the foreign good, then the foreign trade intervention will result in higher domestic welfare.

\footnotetext{
${ }^{11}$ See Beath and Katsoulacos (1991) for a related discussion.
} 
We have examined the possibility of a passive domestic response for theoretical as well as practical reasons. On the one hand, the existing literature has not addressed this particular aspect of the strategic trade literature. But more importantly, we would like to know whether a government committed to laissezfaire policies might be acting appropriately even in the face of a "sophisticated" strategic trade policy abroad. Our results certainly suggest a positive response to this question; in many plausible situations, a domestic government pursuing a "hands-off" attitude towards foreign strategic trade intervention need not fear that overall domestic welfare would fall.

One should also recognize that many of the basic results of this paper arise out of the second-best world we are analyzing. ${ }^{12}$ In the Cournot case, we see that the initial Nash equilibrium entails too little world production because of the oligopolistic nature of the Nash competition. The foreign export subsidy increases production, decreases prices, and benefits domestic consumers in excess of the domestic profit loss. Not surprisingly, government intervention in a distorted market allows for possible welfare improvement. The Bertrand case is the mirror image. While the foreign intervention may result in a domestic welfare improvement, it need not. Once again, the ambiguity of the impact of the interven-tion is not surprising since we are in a distorted market to begin with.

In short, we have provided yet another argument for governments resisting the temptation to intervene in international trade, even in the presence of oligopolistic rents and aggressive foreign intervention.

Received June 2002, Accepted 17 February 2003

\section{References}

Anderson, S.P. N. Schmitt and J.-F. Thisse, (1995), "Who benefits from antidumping legislation?", Journal of International Economics, 38, 321-337.

Bandyopadhyay, S. (1997), "Demand elasticities, asymmetry and strategic trade policy", Journal of International Economics, 42, 167-177.

Beath, J. and Y. Katsoulacos, (1991), The economic theory of product differentiation, Cambridge University Press, Cambridge.

Blonigen B.A., J.E. Flynn and M. P. Gallaway, (1999), "Welfare costs of the U.S. antidumping and countervailing duty laws", Journal of International Economics, 49, 211-244.

Brander J. and B.J. Spencer, (1981), "Tariffs and the extraction of monopoly rents under

\footnotetext{
${ }^{12}$ This helpful interpretation was provided by a referee.
} 
potential entry", Canadian Journal of Economics, 14, 371-389.

Brander, J. and B.J. Spencer, (1984), "Trade warfare: tariffs and cartels", Journal of International Economics, 18, 83-100.

Brander, J. and B.J. Spencer, (1985), "Export subsidies and international market share rivalry", Journal of International Economics, 18, 83-100.

Brander, J., (1995), "Strategic trade policies", in Handbook of International Economics, Vol. 3, G. Grossman and K. Rogoff, ed. Elsevier, Amsterdam.

Brainard, L. et D. Martimort, (1987), "Strategic trade policy with incompletely informed policy makers", Journal of International Economics, 42, 33-65.

Bulow, J., J. Geanakolos and P. Klemperer, (1985), "Multimarket oligopoly: strategic substitutes and complements", Journal of Political Economy, 93, 488-511.

Caillaud, B., B. Julien and P. Picard, (1995), "Competing vertical structures: precommitment and renegotiation", Econometrica, 63, 621-646.

Carmichael, C., (1987), "The role of export credit subsidies and its welfare consequences", Journal of International Economics, 23, 1-19.

Cheng, L., (1988), "Assisting domestic industries under international oligopoly: The relevance of the nature of competition to optimal policies", American Economic Review, 78, 746-758.

Collie, D., (1991a), "Antidumping and countervailing duties under oligopoly - A comment", European Economic Review, 35, 1185-1187.

Collie, D., (1991b), "Export subsidies and countervailing tariffs", Journal of International Economics, 31, 309-324.

Dixit, A., (1984), "International trade policy for oligopolistic industries", Economic Journal, 94, 1-16.

Dixit, A., (1988), "Antidumping and countervailing duties under oligopoly”, European Economic Review, 32, 55-68.

Eaton, J. and G. Grossman, (1985), "Optimal trade and industrial policy under oligopoly", Quarterly Journal of Economics, 101, 383-406.

Gruenspecht, H., (1988), "Export subsidies for differentiated products", Journal of International Economics, 24, 331-344.

Kreps, D. and J. Scheinkman, (1983), "Quantity precommitment and Bertrand competition yield Cournot outcomes", Bell Journal of Economics, 14, 326-337.

Laussel, D. (1992), "Strategic commercial policy revisited: a supply-function equilibrium model", American Economic Review, 82, 84-99.

Maggi, G. (1996), "Strategic trade policies with endogenous mode of competition", American Economic Review, 86, 237-258.

Neary, P. (1994), "Cost asymmetries in international subsidy games: should governments help winners or losers?", Journal of International Economics, 31, 309-324.

Singh, N. and X. Vives, (1984), "Price and quantity competition in a differentiated duopoly", RAND Journal of Economics, 14, 326-337.

Van, Long N. and A. Soubeyran, (1997), "Cost heterogeneity, industry concentration and strategic trade policies", Journal of International Economics, 43, 207-220. 


\title{
Domestic Welfare Effects of Foreign Strategic Trade Policies
}

\author{
Philippe Kohler \\ Institut d'Etudes Politiques de Paris \\ Michael O. Moore \\ The George Washington University
}

\begin{abstract}
Within a duopoly strategic trade policy model, we analyze the effect of foreign strategic trade policies on domestic welfare when the domestic government pursues a laissez-faire import policy. With Cournot competition and domestic production and consumption, an increase in the foreign strategic export subsidy increases domestic welfare when the domestic price exceeds the foreign firm marginal cost. With Bertrand competition, an increase in the foreign strategic export tax has ambiguous effects on domestic welfare and depends on the degree of product differentiation and domestic cross-price elasticity of demand between domestic and foreign goods.
\end{abstract}

- JEL Classifications: F13

- Key words: Dumping, Laissez-faire policy, Strategic trade policy.

\section{Introduction}

Even if optimal trade policies under oligopoly have been widely studied ${ }^{1}$ some

\footnotetext{
*Corresponding address: Doctor Philippe Kohler, Institut d'Etudes Politigues de Paris 2, Sguare de Luynes 75007- Paris, France Tel: 33-1-4559-7256, Fax: 31-1-4549-7257, E-mail: philippe.kohler@ sciences-po.fr

Professor Michael O. Moore, The George Washington University, Department of Economics and Elliott School of International Affairs, Washihation DC 20052, USA. Tel: 202-994-6157, Fax: 202-994-6147, E-mail: mom@gwu.edu (C2003-Center for International Economics, Sejong Institution, All Rights Reserved.

${ }^{1}$ See Brander (1995) for an extensive survey.
} 
analytical points have been missed and merit attention. In this paper, we focus on one of those points: the welfare implication of a passive domestic response to active foreign trade policies under oligopoly. We find that in a broad array of situations, domestic welfare is not harmed by adherence to a simple laissez-faire trade policy, even in the face of foreign "optimal" foreign intervention. These results therefore provide further support for countries deciding not to attempt to pursue interventionist "strategic trade policies" and adhering instead to relatively easy-to-implement free trade approaches.

The literature on strategic trade policies has generally taken two directions: on the one hand, emphasis has been put on the design of domestic policies on foreign markets given agents' characteristics. ${ }^{2}$ On the other hand, normative reasons for active responses to foreign policies have been investigated.

Dixit (1988) provides a systematic treatment of this latter approach. He analyzes the domestic optimal trade and industrial policies (including domestic subsidies and tariffs on foreign goods) in response to foreign government subsidies and foreign firm dumping. ${ }^{3}$ In the case of foreign dumping, the main result is that no normative reason can be found to modify the home government optimal strategic policy in order to respond to a modification of the foreign firm strategic choice (i.e., the dumping margin). However, in the case of foreign subsidies, Dixit shows that a countervailing tariff ${ }^{4}$ is justified from a home welfare point of view in order to offset an increase in the foreign government strategic choice (i.e., an export subsidy). Collie (1991b) builds on Dixit by focusing both on foreign incentives for export subsidies in the presence of home retaliation through tariffs and production subsidies and on the home and foreign welfare effect of such retaliation. He finds that a foreign export subsidy always increases domestic welfare if the domestic country pursues an optimal trade policy, but, in some cases, such a response does not negate the profit-shifting argument for export subsidies. If the home government can only use the tariff to countervail the foreign strategic trade policy and if this tariff is set optimally, then it gains from the foreign export subsidy. However, if the foreign country anticipates the

\footnotetext{
${ }^{2}$ One set of authors has focused on the supply side of the model (i.e., the nature of the duopolistic competition). They include Eaton and Grossman (1985), Laussel (1992), and Maggi (1996). (See Caillaud et al. (1995), and Brainard and Martimort (1997) for the treatment and implications of agency problems arising from incomplete information problems.) Others, including Bandopadhya (1997) and Neary (1994) have focused more on the structure of demand.
}

${ }^{3}$ Cheng (1988) develops similar work in this field.

${ }^{4}$ The duty should only partially countervail the foreign policy as shown by Collie (1991a). 
home optimal response, the foreign incentives for profit shifting subsidy shift into an export tax motive.

Collie (1991b) thus points out that "rational" strategic foreign export subsidies generally only exist when optimal home optimal responses do not. In the case of anticipated home retaliation through tariffs, the optimal strategic trade policy is an export tax. Our paper follows Collie (1991b) but adopts a complementary approach by assuming that the domestic government does not intervene in response to the foreign strategic trade policy. We analyze this issue first with a strategic foreign export subsidy and second in the case of a foreign export tax. In each case, we ask how home welfare is affected by these policies when the home country does not intervene.

We assume that domestic welfare consists of the sum of consumer surplus and producer profit so that tariff/subsidy budget effects are ignored. We show that with Cournot competition (i.e., when strategic variables are substitutes), while the domestic firm suffers from the foreign subsidy, the home country's consumers always gain enough from a small increase in the strategic foreign subsidy to increase net domestic welfare, as long as the foreign firm's price exceeds its marginal production cost, i.e., it is not dumping. In the Bertrand case with differentiated products (strategic complements), the foreign export tax helps the domestic firm but harms the domestic consumer. The net effect on domestic welfare with a domestic laissez-faire policy depends on a number of parameters, including most importantly the cross-price elasticity of domestic demand between domestic and foreign output. But once again, we find that domestic welfare can rise with foreign optimal intervention. ${ }^{5}$

\section{Welfare Effects of Strategic Trade Policies in the Case of a Laissez-faire policy}

\section{A. Cournot Competition-Strategic Substitutes}

Consider a domestic and a foreign firm producing a homogenous good and competing in a Cournot fashion. For the sake of simplicity, the domestic firm's output is produced only for its home market while the foreign firm sells all of its output $y$ in

\footnotetext{
${ }^{5}$ Anderson et al. (1995) analyze antidumping tariffs in a Bertrand and Cournot model and find similarly that no intervention would be optimal for the domestic government. Blonigen et al.(1999) also find in computable general equilibrium model that duties placed on "unfairly" traded imports have significant welfare costs.

${ }^{6}$ This setup is therefore slightly different from the standard Brander-Spencer model in which the countries' two duopolies compete in a third market.
} 
the domestic market. ${ }^{6}$ Total domestic supply of the good is given by $Q=y+x$ and $P(Q)$ denotes the domestic inverse demand for the good. Within the Cournot duopolistic interaction, quantities act as strategic substitutes: a marginal increase of the foreign firm supply reduces the domestic firm marginal profit. The domestic firm has to reduce its own supply in order to restore its profit maximization condition, i.e., a zero marginal profit.

In this case, we analyze the welfare impact of a foreign strategic subsidy when the domestic government pursues a unilateral laissez-faire trade policy: no tariff revenue is collected nor is a domestic subsidy granted. Domestic welfare $W$ is thus given by the sum of consumer surplus $C S$ and domestic profit $\pi$.

$$
W=C S+\pi
$$

where $C S$ is given by:

$$
\int_{0}^{Q} P(v) \cdot d v-P(Q) \cdot Q
$$

The domestic (foreign) production technologies are based on a constant marginal cost $c\left(c^{*}\right)$ and a fixed cost $F\left(F^{*}\right) .{ }^{7}$ We assume that the foreign government policy consists of choosing the per-unit strategic export subsidy level $s^{*}$ to maximize foreign welfare. Domestic and foreign profits are, respectively:

$$
\begin{gathered}
\pi(x, y)=(P(Q)-c) \cdot x-F \\
\pi^{*}(x, y)=\left(P(Q)-c^{*}+s^{*}\right) \cdot y-F^{*}
\end{gathered}
$$

As in the standard case, the strategic rent shifting effect allowed by the foreign subsidy can be shown by computing and differentiating the first order conditions for domestic and foreign profit maximization in the duopoly:

$$
\begin{gathered}
\pi_{x}=\frac{d \pi(x, y)}{d x}=P-c+x \cdot P^{\prime}=0 \\
\pi_{y^{*}}=\frac{d \pi^{*}(x, y)}{d y}=P-c^{*}+s^{*}+y \cdot P^{\prime}=0
\end{gathered}
$$

where $P^{\prime}=d P / d Q<0$. Following Brander and Spencer (1985), at the CournotNash equilibrium, the foreign optimal strategic subsidy, denoted by $\tilde{s}^{*}$, is given by:

$$
\tilde{s}^{*}=\pi_{x^{*}} \cdot \frac{d x / d s^{*}}{d y / d s^{*}}=-\pi_{x^{*}} \frac{\pi_{x y}}{\pi_{x x}}=y \cdot P^{\prime} \cdot \frac{d x / d s^{*}}{d y / d s^{*}}
$$

${ }^{7}$ Foreign variables are denoted with an asterisk. Subscripts refer to derivatives. 
where:

$$
\pi_{x x} \equiv \partial^{2} \pi / \partial x^{2}, \pi_{x y} \equiv \partial \pi_{x} / \partial y, \pi_{y x}^{*} \equiv \partial \pi_{y}^{*} / \partial x, \pi_{y y}^{*} \equiv \partial^{2} \pi / \partial y^{2}
$$

Assuming stability of the Nash equilibrium and that decision variables are strategic substitutes, we have the standard result that the foreign optimal export subsidy is positive. As is well known in these models, domestic output falls as a consequence of the subsidy, $d x / d s^{*}<0$, while foreign output rises: $d x / d s^{*}>0$. Moreover, foreign output rises more than domestic output falls so that total supply in the domestic market rises, i.e., $d Q / d s^{*}>0$.

From a domestic welfare viewpoint, Dixit (1988) and Collie (1991b) have shown that foreign subsidies are desirable when the domestic government can respond optimally through the extraction of the shifted rent with a tariff on imports. However, Brander and Spencer (1984) had also shown that, with no domestic production, the efficient response to foreign firm market power can be an import subsidy. ${ }^{8}$ We ask a different question: are foreign subsidies harmful when the domestic government's policy is free trade? In other words, if a government decides to follow the simplest of all trade rules (non-intervention), will domestic welfare be hurt by the foreign attempts to increase firm rents?

Taking into account the situation where the foreign government sets the optimal value of the subsidy, we compute the domestic welfare change in a hypothetic situation where the optimal subsidy level is increased at the margin. If the domestic welfare varies positively (negatively) with the foreign subsidy, then the foreign use of subsidy is domestically welfare improving (worsening) if the domestic government retains a laissez-faire policy. ${ }^{9}$

Consider first domestic welfare, which can be re-written as:

$$
W=\int_{0}^{Q} P(v) \cdot d v-P(Q) \cdot Q+(P-c) \cdot x-F
$$

\footnotetext{
${ }^{8}$ This points out the second best nature of the problem: the subsidy reduces the imperfect competition distortion.

${ }^{9} \mathrm{We}$ assume that the domestic welfare varies monotonically with the optimal level of the foreign export subsidy.

${ }^{10}$ One can argue that $s^{*}$ is determined endogenously and depends on $\pi$ or, more accurately, on $c$. If we assume that $c$ is constant then $s^{*}$ depends exclusively on parameters exogenous to domestic firm characteristics (see Collie (1991b) for an analogous derivation method).
} 
The domestic welfare effect of a change in the foreign subsidy $s^{*}$ is given by the sum of consumers and firm profit effects: ${ }^{10}$

$$
\frac{d W}{d S^{*}}=\frac{d C S}{d s^{*}}+\frac{d \pi}{d s^{*}}
$$

The domestic consumer surplus effect of the subsidy increase is given by:

$$
\frac{d C S}{d s^{*}}=P \cdot \frac{d Q}{d s^{*}}-\left[P \cdot \frac{d Q}{d s^{*}}+Q \cdot P^{\prime} \cdot \frac{d Q}{d s}\right]=-Q \cdot P^{\prime} \cdot \frac{d Q}{d s^{*}}
$$

Expression (11) shows that the consumer surplus rises with an increase in the foreign subsidy since overall supply increases $\left(d Q / d s^{*}>0\right)$ and the demand curve is downward sloping $\left(P^{\prime}<0\right)$.

On the other hand, the effect of the subsidy change on domestic profits is given by:

$$
\frac{d \pi}{d s^{*}}=(P-c) \cdot \frac{d x}{d s^{*}}+x \cdot P^{\prime} \cdot \frac{d Q}{d s^{*}}<0
$$

Since we know that $d Q / d s^{*}>0$ and that overall supply rises, domestic profit falls with the increase in the foreign subsidy. Given that $Q=x+y$, the overall domestic welfare effect of a subsidy increase is therefore given by:

$$
\frac{d W}{d s^{*}}=-y \cdot P^{\prime} \cdot \frac{d y}{d s^{*}}+\left(P-c-y \cdot P^{\prime}\right) \cdot \frac{d x}{d s^{*}}
$$

Thus, an increase of the foreign subsidy will increase domestic welfare if:

$$
\frac{d W}{d s^{*}}>0 \Leftrightarrow-y \cdot P^{\prime} \cdot \frac{d y}{d s^{*}}+\left(P-c-y \cdot P^{\prime}\right) \cdot \frac{d x}{d s^{*}}>0
$$

Dividing the right hand side of this expression by $P$ yields:

$$
\left[\frac{-y \cdot P}{P} \cdot \frac{d y}{d s^{*}}\right]+\left[\frac{P-c}{P}-\frac{y \cdot P^{\prime}}{P}\right] \cdot \frac{d x}{d s^{*}}>0
$$

Let $\varepsilon$ denote the price elasticity of the inverse demand on the home market and $z\left(z^{*}\right)$, the market share of the domestic (foreign) firm:

$$
\varepsilon \equiv \frac{P}{-Q \cdot P^{\prime}} \quad z \equiv \frac{x}{Q} \quad z^{*} \equiv \frac{y}{Q}
$$

By using (16), we can rewrite condition (15) as: 


$$
\frac{z^{*}}{\varepsilon} \cdot\left[\frac{d x}{d s^{*}}+\frac{d y}{d{ }^{*}}\right]+\left[\frac{P-c}{P}\right] \cdot \frac{d x}{d s^{*}}>0
$$

In (17), the first term (positive) exhibits a consumption effect due to the net supply variation of the good in the domestic economy and the second term (negative) denotes a domestic firm profit effect due to the loss of the domestic firm as it reduces its output.

Condition (17) shows that the smaller is the foreign share in the domestic market, the smaller is the positive consumption effect of the increased subsidy and the more likely that the domestic firm profit negative effect will dominate. In a Cournot duopoly, a low foreign firm market share in the domestic market implies a high foreign marginal cost relative to the domestic firm marginal cost. As shown by Neary (1994), such a situation implies an intrinsically low optimal foreign strategic export subsidy: the profit shifting effect of the export subsidy is low. Paradoxically, domestic consumers are thus negatively affected by the inefficiency of the foreign firm. In addition, the more elastic domestic demand, the less important will be the consumption positive effect. In the limit, a perfectly elastic domestic demand curve will mean that the only effect will be the domestic firm profit negative effect. These conditions for a welfare improvement will hold for any foreign subsidy increase that causes domestic output to fall but overall supply in the domestic market to increase.

Now what is the domestic welfare effect of a marginal increase in a subsidy chosen optimally (i.e.; $s^{*}=\tilde{s}^{*}$ ) by the foreign government? We can use the domestic firm's first-order conditions (6) as well as the definition of $\varepsilon$ to re-write the domestic price-cost markup as:

$$
\frac{P-c}{P}=-\frac{x \cdot P^{\prime}}{P}=\frac{x}{Q} \cdot \frac{-Q \cdot P^{\prime}}{P}=\frac{z}{\varepsilon}
$$

Using (18) along with the formula for the optimal foreign subsidy (7) allows us to provide another version of the condition (17) for a domestic welfare improvement:

$$
\left[\frac{z}{\varepsilon}+\frac{z^{*}}{\varepsilon}\right] \cdot\left[\frac{d x}{d \tilde{s}^{*}} / \frac{d y}{d \tilde{s}^{*}}\right] \cdot \frac{P-c}{P}>-\frac{z^{*}}{\varepsilon}
$$

Condition (19) is equivalent to:

$$
\frac{\tilde{s}^{*}}{\varepsilon \cdot y \cdot P^{\prime}}>-\frac{z^{*}}{\varepsilon}
$$


Consider the right hand side of (20). Given that $\varepsilon>0$ and $y \cdot P^{\prime}<0$, the home welfare effect is positive if:

$$
\tilde{s}^{*}<-y \cdot P^{\prime} \cdot z^{*}
$$

Using the fact that $-y \cdot P^{\prime}=P / \varepsilon$, condition (21) can be rewritten as:

$$
\frac{\tilde{s}^{*}}{P}<\frac{z^{*}}{\varepsilon}=\frac{-y \cdot P^{\prime}}{P}
$$

We know from (6) that $-y \cdot P^{\prime}=\left(P-c^{*}+\tilde{s}^{*}\right)$. Hence, condition (22) can be rewritten as

$$
\frac{\tilde{s}^{*}}{P}<\frac{P-c^{*}+\tilde{s}^{*}}{P}
$$

Thus, an increase in the optimal foreign subsidy will increase domestic welfare only if:

$$
\left.\frac{d W}{d s^{*}}\right|_{s^{*}=\tilde{s}^{*}}>0 \Leftrightarrow P-c^{*}>0
$$

Condition (24) allows us to give the following proposition:

Proposition 1. With strategic substitutes, an increase in the optimal foreign strategic subsidy increases the welfare of a laissez-faire domestic economy, as long as the foreign firm's price in the domestic market exceeds its own marginal production cost.

If the foreign firm is selling below its production cost then a marginal increase in the optimal foreign export subsidy will decrease domestic welfare. One might be tempted to interpret this result as a justification for antidumping and countervailing duty laws - if the foreign firm is uncompetitive and must use a subsidy to overcome its high costs, then the domestic consumer benefits of the lower prices is outweighed by the "inappropriate" shifting of profits from the costefficient domestic firm. However, would it ever make economic sense for the foreign government to subsidize a loss-making firm? In particular, since foreign welfare is given by:

$$
W^{*}=\left(P(Q)-c^{*}+s^{*}\right) \cdot y-F^{*}-s^{*} \cdot y=\left(P(Q)-c^{*}\right) \cdot y-F^{*}
$$


any positive foreign production yields negative welfare. Thus, no foreign subsidy and no foreign production should occur for governments with this objective function.

If instead the foreign firm does cover its costs through exports to the domestic market, then an increase in the foreign government's optimal subsidy will increase domestic consumer welfare enough to offset any profit loss. When might the foreign subsidy increase beyond the original optimal level?

One possibility is that the foreign government might inadvertently increase the subsidy beyond the optimal level, say, because of poor information about the foreign firm market structure. This increased subsidy will increase overall foreign firm output beyond the optimal level; i.e., too much output, too low a price, and too high of a subsidy cost. Nonetheless, as long as the foreign firm is not dumping, then the falling prices in the domestic market is beneficial to overall domestic welfare. This result is not that different from standard perfectly competitive frameworks-a subsidy generally will help consumers more than it hurts domestic firms.

\section{B. Bertrand Competition-Strategic Complements}

Consider now the Bertrand duopoly case. Denote the domestic demand for the domestic firm output (the foreign firm output) by $x\left(P, P^{*}\right)\left(y\left(P, P^{*}\right)\right)$, where $P\left(P^{*}\right)$ is the price set by the domestic firm (foreign firm). We assume that the domestic and foreign goods are imperfect substitutes in domestic consumption, $x_{P^{*}}>0$ and $y_{P}>0$ so that prices act as strategic complements: a marginal increase of the foreign firm price increases the domestic firm marginal profit. The domestic firm has to increase its own price in order to restore its profit maximization condition, i.e.; a zero marginal profit.

In this case, the foreign trade policy consists of committing to impose an export $\operatorname{tax} t^{*}$ on the output sold by the foreign firm in the domestic market. Domestic firm and foreign firm profit functions are, respectively:

$$
\begin{gathered}
\pi\left(P, P^{*}\right)=(P-c) \cdot x\left(P, P^{*}\right)-F \\
\pi^{*}\left(P, P^{*}, t^{*}\right)=\left(P-c^{*}-t^{*}\right) \cdot y\left(P, P^{*}, t^{*}\right)-F^{*}
\end{gathered}
$$

Taking $t^{*}$ as given, firms set prices in a Bertrand context in order to maximize their profits. First order conditions are given by: 


$$
\begin{gathered}
\pi_{P}=\frac{\partial \pi}{\partial P}=x_{P} \cdot(P-c)+x=0 \\
\pi_{P^{*}}^{*}=\frac{\partial \pi^{*}}{\partial P^{*}}=y_{P^{*}} \cdot\left(P^{*}-c^{*}-t^{*}\right)+y=0
\end{gathered}
$$

Differentiation of first-order conditions and standard computation gives the effect of the foreign export tax on domestic and foreign strategic variables:

$$
\frac{d P}{d t^{*}}>0, \quad \frac{d P^{*}}{d t^{*}}>0
$$

The optimal foreign export tax value denoted by $\tilde{t}^{*}$ emerges from the foreign government welfare maximization problem:

$$
\max _{t^{*}} W^{*}\left(t^{*}\right)=\pi^{*}\left[P\left(t^{*}\right), P^{*}\left(t^{*}\right), t^{*}\right]+t^{*} \cdot y\left[P\left(t^{*}\right), P^{*}\left(t^{*}\right)\right]
$$

and equals:

$$
\tilde{t}^{*}=-\left(P^{*}-c^{*}\right) \cdot \frac{y_{P}}{y_{P^{*}}} \cdot\left[\frac{d P\left(t^{*}\right)}{d t^{*}} / \frac{d P^{*}\left(t^{*}\right)}{d t^{*}}\right]
$$

Expression (17) shows that if the foreign price exceeds foreign cost (i.e., $P^{*}-$ $c^{*}>0$ ), then the optimal policy of the foreign government concerned only with firm profit would be an export tax. If the opposite is true (i.e., $P^{*}-c^{*}<0$ ), then one might expect an optimal export subsidy and the foreign government in fact would not intervene: as in the previous section, it is clear from the definition of foreign welfare that foreign profit net of the tax will always be negative for $P^{*}-c^{*}<0$. The foreign firm will therefore shut down without the subsidy.

Consider now the welfare of the domestic country, defined in a way analogous to (1):

$$
W=\int_{P}^{\infty} x\left(v, P^{*}\right) \cdot d v+\int_{P^{*}}^{\infty} y(P, v) \cdot d v+\pi\left(P, P^{*}\right)
$$

For an arbitrary change in the foreign intervention, we have:

$$
\frac{d W}{d t^{*}}=-x \cdot \frac{d P}{d t^{*}}-y \cdot \frac{d P^{*}}{d t^{*}}+(P-c) \cdot x_{P} \cdot \frac{d P^{*}}{d t^{*}}
$$

In the right-hand side of (34), the first two terms show the consumption effect of the foreign intervention: an export tax increase, with a consequent rise in domestic and foreign prices, will hurt consumers. The third term is the domestic profit effect: a foreign price increase allows for the domestic firm to increase its 
sales and hence its profits. If the profit effect outweighs the consumption effect then the foreign export tax increase improves domestic welfare.

Assume that the foreign government chooses $t^{*}$ optimally. The domestic welfare effect of a marginal change in the neighborhood of the optimal value $\tilde{t}^{*}$ is obtained by combining $d P^{*} / d t^{*}$ from (32) the optimal intervention condition with (34):

$$
\left.\frac{d W}{d t^{*}}\right|_{t^{*}=\tilde{t}^{*}}=\frac{d P}{d t^{*}} \cdot\left[\left(-x-y+(P-c) \cdot x_{P^{*}}\right) \cdot\left(-\left(P^{*}-c^{*}\right) \cdot \frac{y_{P}}{y_{P^{*}}} \cdot P^{*} \cdot \frac{1}{\tilde{t}^{*}}\right)\right]
$$

In (35), assume that the foreign firm is selling above its marginal cost (i.e., $P^{*}$ $\left.-c^{*}>0\right)$. Since we have $y_{p}<0$ and $y_{P^{*}}>0$, the domestic welfare effect of the optimal foreign export tax increase will depend on whether $\left(-x-y+(P-c) \cdot x_{P^{*}}\right)$ is positive. This condition simply shows the induced marginal impact on domestic consumers as domestic and foreign prices rise as well as the marginal domestic firm profit effect due to the foreign price increase.

Using (35), we can rewrite the condition for a domestic welfare improvement as:

$$
\frac{P-c}{P}>\frac{P^{*}}{P} \cdot \frac{1}{\varepsilon_{x / y}} \cdot\left[\frac{\tilde{t}^{*}}{P^{*}-c^{*}} \cdot\left(-\frac{y_{P^{*}}}{y_{P}}\right)+\frac{y}{x}\right]
$$

with:

$$
\varepsilon_{x / y}=\frac{\partial x}{\partial P^{*}} \cdot \frac{P^{*}}{x}
$$

Condition (36) relates the domestic price-cost markup to two domestic demand parameters: the cross-price elasticity of domestic demand $\varepsilon_{x / y}$ and the degree of products differentiation.

First, if $\varepsilon_{x / y}$ is sufficiently high, then the increase in the foreign tax is welfareimproving. This means that the domestic firm could see sufficient strength in domestic sales and the subsequent higher domestic profits to offset the increased burden on domestic consumers. Thus, unlike the Cournot case, it is not enough to show that foreign firms are not dumping for the foreign scheme to be welfareenhancing: it depends on how much domestic consumers switch their consumption of domestic output relatively to foreign output as prices increase as a consequence of the foreign government intervention.

Second, in the case of linear demands, $-y_{P^{*}} / y_{P}$ can be considered the brands' measure of differentiation (BMD). In particular, suppose that differentiated demands are given by $x=a-b P+c P^{*}$ and $y=a+c P-b P^{*}$ then the BMD is 
given by $-y P^{*} / y P$ which equals $c / b$. Thus, a BMD is close to zero (one) for highly differentiated (almost homogeneous) brands. ${ }^{11}$

It is clear from (36) that as BMD approaches zero, the more likely it is that an increase in the foreign export intervention will improve domestic welfare-close substitutes makes the price collusion device induced by the export tax more difficult to implement. The reverse is true-as the degree of differentiation rises (i.e., BMD approaches 1), the less likely it is that the increased foreign intervention will increase domestic welfare.

The following proposition summarizes the interpretation of condition (36):

Proposition 2. With strategic complements and domestic laissez-faire, an increase in the optimal foreign intervention is more likely to increase domestic welfare: a) the larger is $\varepsilon_{x / y} b$ ) the less differentiated are the domestic and foreign products $c$ ) the larger is the domestic price-cost markup d) the smaller the value of foreign imports relative to the value of domestic production.

\section{Concluding Remarks}

Within a duopoly model of strategic trade policy, we have studied the welfare implications of a domestic government's passive response to a foreign strategic intervention. The domestic government laissez-faire policy consists of ignoring any possibility of increasing tariff revenues or subsidizing the domestic firm. Instead, the government considers only the sum of domestic consumer surplus and domestic profit.

With strategic substitutes under Cournot-Nash competition, a foreign export subsidy will increase domestic welfare as long as the foreign production cost is below the price it charges in the domestic market. This result surprisingly mitigates the welfare argument for a home strategic response to a more aggressive foreign firm behavior on a home Cournot duopolistic market.

With Bertrand-Nash competition with differentiated products, the impact of a foreign intervention depends mainly on the degree of substitutability between domestic and foreign goods. If a change in prices causes domestic consumers to switch their purchases sufficiently towards the domestic firm's output from the foreign good, then the foreign trade intervention will result in higher domestic welfare.

\footnotetext{
${ }^{11}$ See Beath and Katsoulacos (1991) for a related discussion.
} 
We have examined the possibility of a passive domestic response for theoretical as well as practical reasons. On the one hand, the existing literature has not addressed this particular aspect of the strategic trade literature. But more importantly, we would like to know whether a government committed to laissezfaire policies might be acting appropriately even in the face of a "sophisticated" strategic trade policy abroad. Our results certainly suggest a positive response to this question; in many plausible situations, a domestic government pursuing a "hands-off" attitude towards foreign strategic trade intervention need not fear that overall domestic welfare would fall.

One should also recognize that many of the basic results of this paper arise out of the second-best world we are analyzing. ${ }^{12}$ In the Cournot case, we see that the initial Nash equilibrium entails too little world production because of the oligopolistic nature of the Nash competition. The foreign export subsidy increases production, decreases prices, and benefits domestic consumers in excess of the domestic profit loss. Not surprisingly, government intervention in a distorted market allows for possible welfare improvement. The Bertrand case is the mirror image. While the foreign intervention may result in a domestic welfare improvement, it need not. Once again, the ambiguity of the impact of the interven-tion is not surprising since we are in a distorted market to begin with.

In short, we have provided yet another argument for governments resisting the temptation to intervene in international trade, even in the presence of oligopolistic rents and aggressive foreign intervention.

Received June 2002, Accepted 17 February 2003

\section{References}

Anderson, S.P. N. Schmitt and J.-F. Thisse, (1995), "Who benefits from antidumping legislation?", Journal of International Economics, 38, 321-337.

Bandyopadhyay, S. (1997), "Demand elasticities, asymmetry and strategic trade policy", Journal of International Economics, 42, 167-177.

Beath, J. and Y. Katsoulacos, (1991), The economic theory of product differentiation, Cambridge University Press, Cambridge.

Blonigen B.A., J.E. Flynn and M. P. Gallaway, (1999), "Welfare costs of the U.S. antidumping and countervailing duty laws", Journal of International Economics, 49, 211-244.

Brander J. and B.J. Spencer, (1981), "Tariffs and the extraction of monopoly rents under

\footnotetext{
${ }^{12}$ This helpful interpretation was provided by a referee.
} 
potential entry", Canadian Journal of Economics, 14, 371-389.

Brander, J. and B.J. Spencer, (1984), "Trade warfare: tariffs and cartels", Journal of International Economics, 18, 83-100.

Brander, J. and B.J. Spencer, (1985), "Export subsidies and international market share rivalry", Journal of International Economics, 18, 83-100.

Brander, J., (1995), "Strategic trade policies", in Handbook of International Economics, Vol. 3, G. Grossman and K. Rogoff, ed. Elsevier, Amsterdam.

Brainard, L. et D. Martimort, (1987), "Strategic trade policy with incompletely informed policy makers", Journal of International Economics, 42, 33-65.

Bulow, J., J. Geanakolos and P. Klemperer, (1985), "Multimarket oligopoly: strategic substitutes and complements", Journal of Political Economy, 93, 488-511.

Caillaud, B., B. Julien and P. Picard, (1995), "Competing vertical structures: precommitment and renegotiation", Econometrica, 63, 621-646.

Carmichael, C., (1987), "The role of export credit subsidies and its welfare consequences", Journal of International Economics, 23, 1-19.

Cheng, L., (1988), "Assisting domestic industries under international oligopoly: The relevance of the nature of competition to optimal policies", American Economic Review, 78, 746-758.

Collie, D., (1991a), "Antidumping and countervailing duties under oligopoly - A comment", European Economic Review, 35, 1185-1187.

Collie, D., (1991b), "Export subsidies and countervailing tariffs", Journal of International Economics, 31, 309-324.

Dixit, A., (1984), "International trade policy for oligopolistic industries", Economic Journal, 94, 1-16.

Dixit, A., (1988), "Antidumping and countervailing duties under oligopoly”, European Economic Review, 32, 55-68.

Eaton, J. and G. Grossman, (1985), "Optimal trade and industrial policy under oligopoly", Quarterly Journal of Economics, 101, 383-406.

Gruenspecht, H., (1988), "Export subsidies for differentiated products", Journal of International Economics, 24, 331-344.

Kreps, D. and J. Scheinkman, (1983), "Quantity precommitment and Bertrand competition yield Cournot outcomes", Bell Journal of Economics, 14, 326-337.

Laussel, D. (1992), "Strategic commercial policy revisited: a supply-function equilibrium model", American Economic Review, 82, 84-99.

Maggi, G. (1996), "Strategic trade policies with endogenous mode of competition", American Economic Review, 86, 237-258.

Neary, P. (1994), "Cost asymmetries in international subsidy games: should governments help winners or losers?", Journal of International Economics, 31, 309-324.

Singh, N. and X. Vives, (1984), "Price and quantity competition in a differentiated duopoly", RAND Journal of Economics, 14, 326-337.

Van, Long N. and A. Soubeyran, (1997), "Cost heterogeneity, industry concentration and strategic trade policies", Journal of International Economics, 43, 207-220. 